\title{
Anaerobic corrosion of carbon steel in compacted bentonite exposed to natural Opalinus clay porewater: Bentonite alteration study
}

\author{
Nikoleta Morelová $^{1}$, Kathy Dardenne ${ }^{1}$, Nicolas Finck ${ }^{1}$, Frank Heberling $^{1}$, Volker Metz ${ }^{1}$, Dieter Schild ${ }^{1}$, \\ Horst Geckeis ${ }^{1}$, and Nikitas Diomidis ${ }^{2}$ \\ ${ }^{1}$ Institute for Nuclear Waste Disposal (INE), Karlsruhe Institute of Technology, \\ Hermann-von-Helmholtz Platz 1, 76344, Eggenstein-Leopoldshafen, Germany \\ ${ }^{2}$ NAGRA, Hardstrasse 73, 5430, Wettingen, Switzerland \\ Correspondence: Nikoleta Morelová (nikoleta.morelova@kit.edu)
}

Published: 10 November 2021

\begin{abstract}
Carbon steel is a potential canister material for the disposal of high-level radioactive waste in deep geological repositories in clays and clay rocks. Bentonite is considered as a potential backfill material for those multi-barrier systems.

To predict the long-term performance and for safety assessment the knowledge of canister corrosion behavior is important. The corrosion products formed and mineralogically altered bentonite at the canister/bentonite interface can potentially provide an additional barrier against radionuclide migration.

In-situ corrosion experiments were performed at the Mont Terri underground research laboratory. Coupons of carbon steel were embedded in Volclay MX-80 bentonite with controlled densities, installed in a borehole under simulated repository and anaerobic conditions and exposed to natural Opalinus clay porewater for a period up to 5.5 years (Smart et al., 2017). In the present study, the bentonite layer at the canister/bentonite interface was characterized by complementary microscopic and spectroscopic techniques (XPS, SEM-EDX, $\mu$ XANES) under anoxic conditions.

The interface revealed reddish-brown staining up to $2 \mathrm{~mm}$ depth into the bentonite in the zone adjacent to the steel in all three obtained samples. The XPS analysis revealed formation of sulfides at the interface consisting of iron and other trace metals present in the steel. The SEM-EDX analyses of the interface (embedded cross-cut with steel removed) showed different degrees of calcium enrichment in the bentonite adjacent to the metal for various samples.

The $\mu \mathrm{XRF}$ analysis performed on the bentonite at the interface showed a scarce or distinct calcium-enriched rim up to $100 \mu \mathrm{m}$ into the bentonite and iron-enriched rim depending on the sample (one sample in Fig. 1), while $\mu$ XANES analysis revealed formation of iron silicate compounds in the reacted reddish-brown zone. The iron appears to displace calcium from the interlayer sites in montmorillonite. The calcium then precipitates at the interface as calcite. The extent of this process seems to be strongly related to the bentonite density. The steel coupon was removed prior to embedding, with the location marked as resin in Fig. 1. A line scan from the edge towards the bulk bentonite did not indicate any systematic gradient in the $\mathrm{Fe}^{2+/ 3+}$ ratio. The formation of mixed $\mathrm{Fe}^{2+/ 3+}$ silicate compounds appears to be heterogeneous.
\end{abstract}

This work contributes to an increasing understanding of steel corrosion mechanisms in clay, which can improve the robustness of canister lifetime predictions.

Kurzfassung. Kohlenstoffstahl ist ein potenzieller Behälterwerkstoff für die Endlagerung hochradioaktiver Abfälle in geologischen Tiefenlagern in Ton und Tongestein. Bentonit wird als potenzielles Verfüllmaterial für diese Mehrbarrierensysteme angesehen.

Für die Vorhersage des Langzeitverhaltens und die Sicherheitsbewertung ist die Kenntnis des Korrosionsverhaltens der Behälter wichtig. Die gebildeten Korrosionsprodukte und der mineralogisch veränderte Bentonit an 
der Grenzfläche zwischen Behälter und Bentonit können möglicherweise eine zusätzliche Barriere gegen die Migration von Radionukliden bilden.

In-situ-Korrosionsexperimente wurden im unterirdischen Forschungslabor von Mt. Terri durchgeführt. Kohlenstoffstahl wurde in Volclay MX-80-Bentonit mit kontrollierter Dichte eingebettet, in einem Bohrloch unter simulierten Endlager- und anaeroben Bedingungen installiert und über einen Zeitraum von bis zu 5,5 Jahren natürlichem Porenwasser aus Opalinuston ausgesetzt (Smart et al., 2017). In der vorliegenden Studie wurde die Bentonitschicht an der Grenzfläche zwischen Kanister und Bentonit durch ergänzende mikroskopische und spektroskopische Techniken (XPS, SEM-EDX, $\mu$ XANES) unter anoxischen Bedingungen charakterisiert.

Die Grenzfläche wies bei allen drei Proben rötlich-braune Verfärbungen auf, die bis zu einer Tiefe von $2 \mathrm{~mm}$ in den Bentonit hineinreichten, und zwar in dem Bereich, der an den Stahl angrenzte. Die XPS-Analyse ergab die Bildung von Sulfiden an der Grenzfläche, die aus Eisen und anderen im Stahl vorhandenen Spurenmetallen bestehen. Die SEM-EDX-Analysen der Grenzfläche (eingebetteter Querschnitt mit entferntem Stahl) zeigten für die verschiedenen Proben einen unterschiedlichen Grad der Kalziumanreicherung im Bentonit in der Nähe des Metalls.

Die $\mu$ XRF-Analyse des Bentonits an der Grenzfläche zeigte je nach Probe (eine Probe in Abb. 1) einen spärlichen oder ausgeprägten kalziumangereicherten Rand bis zu $100 \mu \mathrm{m}$ im Bentonit und einen eisenangereicherten Rand, während die $\mu$ XANES-Analyse die Bildung von Eisensilikatverbindungen in der reagierten rotbraunen Zone ergab. Das Eisen scheint Kalzium aus den Zwischenschichten des Montmorillonits zu verdrängen und wird dann an der Grenzfläche als Kalzit ausgeschieden. Das Ausmaß dieses Prozesses scheint stark von der Bentonitdichte abhängig zu sein. Die Stahlprobe wurde vor dem Einbetten entfernt, wobei die Stelle in Abb. 1 als Harz markiert wurde. Ein Zeilenscan vom Rand in Richtung Bentonitmasse zeigte keinen systematischen Gradienten im $\mathrm{Fe}^{2+/ 3+}$-Verhältnis. Die Bildung von gemischten $\mathrm{Fe}^{2+/ 3+}$-Silikatverbindungen scheint heterogen $\mathrm{zu}$ sein.

Diese Arbeit trägt zu einem besseren Verständnis der Stahlkorrosionsmechanismen in Ton bei, was die Robustheit von Vorhersagen über die Lebensdauer von Behältern verbessern kann.

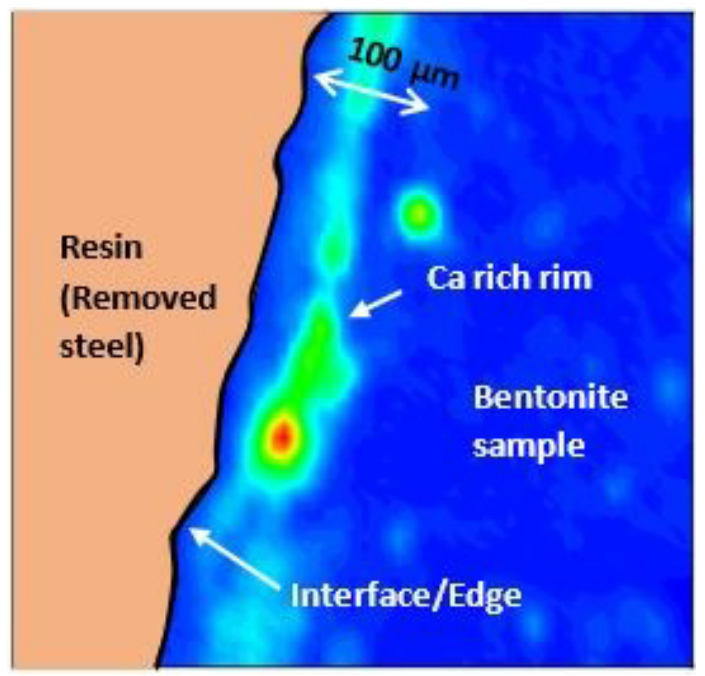

Figure 1. The $\mu \mathrm{XRF}$ map of the interface. Map size: $900 \mu \mathrm{m} \times$ $900 \mu \mathrm{m}$.
Acknowledgements. This work received partial funding from the German Federal Ministry for Education and Research through the iCross collaborative project under grant agreement 02NUK $053 \mathrm{C}$, and from the Helmholtz association under grant agreement SO-093. We thank the Mont Terri IC-A Partners and Swisstopo for providing the samples. We acknowledge the provision of the beamtime at the KIT Light Source, KARA, Germany.

Financial support. This research has been supported by the Bundesministerium für Bildung und Forschung (grant no. 02NUK $053 \mathrm{C}$ ) and the Helmholtz Association (grant no. SO-093).

\section{References}

Smart, N. R., Reddy, B., Rance, A. P., Nixon, D. J., Frutschi, M., Bernier-Latmani, R., and Diomidis, N.: The anaerobic corrosion of carbon steel in compacted bentonite exposed to natural Opalinus Clay porewater containing native microbial populations, Corros. Eng. Sci. Techn., 52, 101-112, 2017. 